Original Research

\title{
The Ventilation Path Assessment of Urban Street in Wuhan
}

\author{
Jie Yin ${ }^{1,2}$, Qingming Zhan', Muhammad Tayyab ${ }^{3,4 *}$ \\ ${ }^{1}$ College of Civil Engineering and Architecture, China Three Gorges University, No. 8, \\ University Road, Xiling District, Yichang City, China \\ ${ }^{2}$ School of Urban Design of Wuhan University, No. 8, Donghu South Road, Wuchang District, Wuhan, China \\ ${ }^{3}$ College of Hydraulic and Environmental Engineering, , Three Gorges University, No. 8, \\ University Road, Xiling District, Yichang City, China \\ ${ }^{4}$ College of Economics and Management China, Three Gorges University, No. 8, \\ University Road, Xiling District, Yichang City, China
}

Received: 27 July 2020

Accepted: 16 November 2020

\begin{abstract}
The urban ventilation path can help to alleviate the heat island effect and air pollution. The building ventilation method is based on building front area density, the building data is divided into grids with numerical attributes, to detect ventilation path. The urban morphology is including building and street, while this building method ignores the ventilation path of the urban street. The streets are most closely connected with people's lives. The direction of the street is the main evaluation index to extract the street ventilation path, which is the supplement of the building method. The spatial analysis technology of Geographic Information System (GIS) was used to calculate the front area density, the street direction, the street length, and the street aspect ratio. These indicators are related to ventilation potential and simulated by Computational Fluid dynamics (CFD). Under different wind directions including the vertical and parallel to the street, it found that the street ventilation potential is different as to the street aspect ratio, if the wind direction is parallel to the street, the street ventilation is better with the decrease of street aspect ratio; if the wind direction is perpendicular to the street, the street ventilation is better with the increase of the street aspect ratio. In the grids of high front area density, there are also some potential ventilation urban streets.
\end{abstract}

Keywords: street ventilation assessment, front area density, street morphological index, geographic information system, computational fluid dynamics

*e-mail: dr.mtayyab@outlook.com 


\section{Introduction}

The Chinese urbanization ratio will exceed $60 \%$. Large-scale urban construction has brought urban heat island effects and urban air pollution [1]. The wind is the most important renewable energy source, urban development intensity will affect the ventilation environment [2, 3], good outdoor ventilation can alleviate the urban heat island effect and air pollution [4-6], the wind environment in urban areas can be complicated and dynamic [7].

The urban ventilation path is the connection between urban heat island and suburban airflow. The ventilation path is generally low-density buildings and green vegetation that can alleviate urban heat islands and air pollution to a certain extent [8-10]. After the natural wind enters the city, the wind speed decreases sharply inside the city because of the building environment [11]. Urban ventilation path assessment is to excavate the urban ventilation path, which is actually to study the relationship between urban building environment and ventilation potential [12]. The building environment elements can be summarized into two parts: buildings and streets (Fig. 1).

It is a critical technology to scientifically and accurately detecting and identifying urban ventilation paths for air path planning, the detecting methods are including Computational Fluid dynamics (CFD) and Geographic Information System (GIS) [13-15]. Frontal area density has a strong negative correlation with wind speed. By calculating the roughness distribution, urban ventilation paths can be detected $[16,17]$. The urban environmental-climate map can mark the main ventilation path and local wind circulation system, which is convenient for planners and government decision-makers to plan and implement [18].

The purpose of digging the street wind path is to improve the city air quality which further improves livability [19]. Computational fluid dynamics (CFD) can simulate the wind field of the street and find the ventilation characteristics of the street shape, Geographic Information System (GIS) can calculate the shape index related to the ventilation potential, thereby quantifying the entire urban area $[20,21]$. These index parameters can assist the planners to draw the local urban climate map, such as average building height, the standard deviation of building height, building density, building volume ratio, building aspect ratio, building surface area density and street aspect ratio, population density, pollutant concentration, land cover type, heat island distribution, and other data indicators have also been added to the identification of ventilation path [22].

In terms of wind environment simulation, the observation data of the meteorological station is simulated and analyzed, and the wind speed and direction are obtained to guide the identification and optimization of the urban ventilation path [23, 24]. However, there are few studies on excavating street ventilation path through GIS. In a two-dimensional front area density grid, the ventilation path of the street will be ignored, the appropriate street form can greatly improve the ventilation environment. The ventilation paths in the streets of Wuhan are excavated as a supplement to the method of excavating building ventilation paths. Based on the extraction of the building's frontal area density ventilation path, this paper summarizes the street shape indicators and extracts the ventilation path of Wuhan streets through the integrated use of Computational fluid dynamics (CFD) numerical simulation and Geographic Information System (GIS) spatial analysis technology. The purpose is to excavate the street ventilation path in areas with higher density. Even in neighborhoods where the area density is high, the street ventilation path can still be detected.

\section{Material and Method}

\section{Study Area and Data}

Wuhan is in the Center of China, the eastern part of Hubei Province, the junction of the Yangtze River and the Han River, and the capital of Hubei Province. The

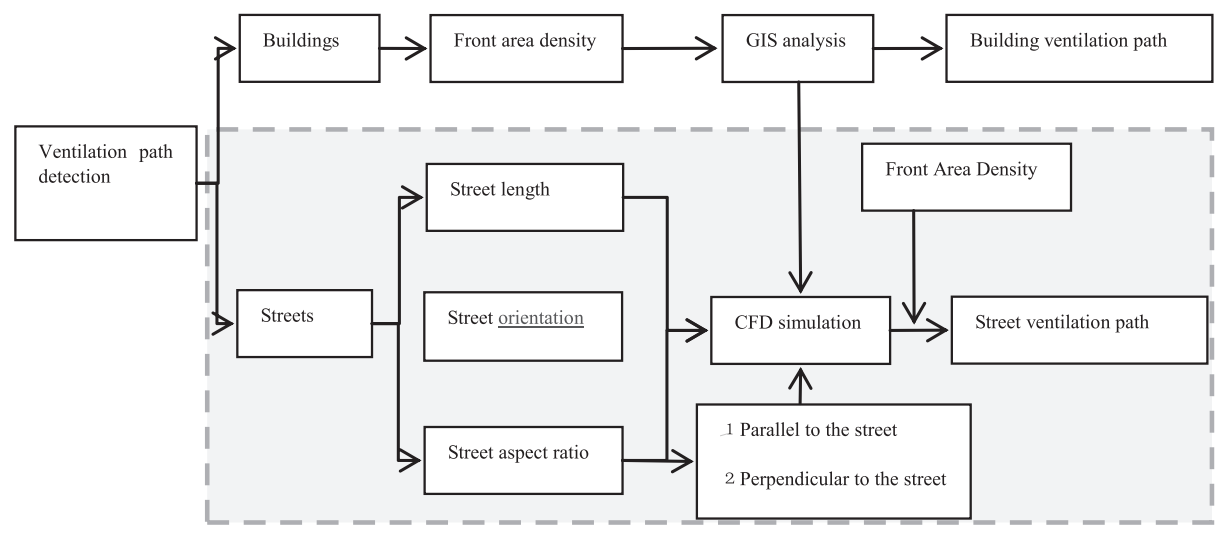

Fig. 1. Ventilation path detection diagram. 

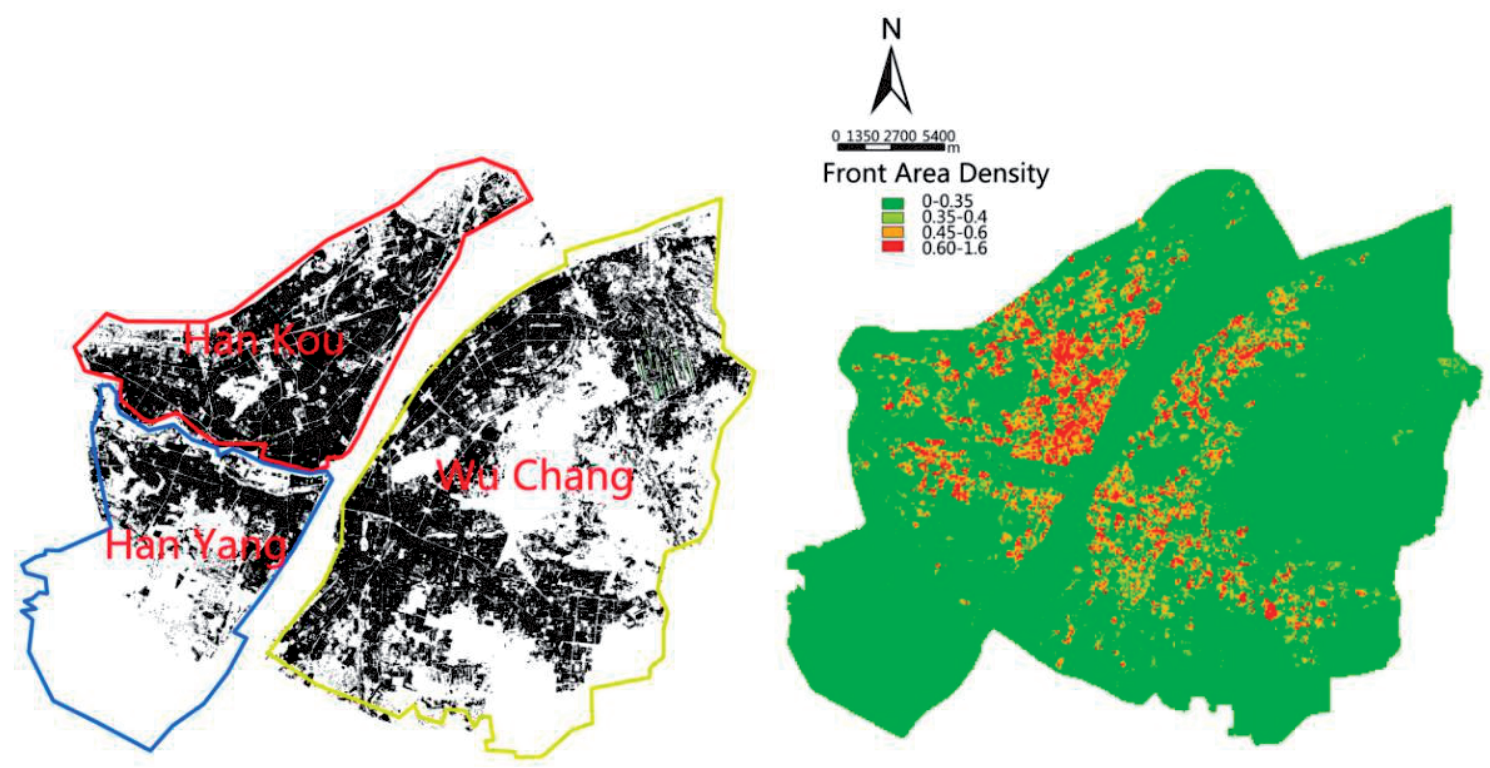

Fig. 2. The construction scope map of Wuhan and the distribution map of Front Area Map.

geographical position is $29^{\circ} 58^{\prime} \sim 31^{\circ} 22^{\prime}$ North latitude and $113^{\circ} 41^{\prime} \sim 115^{\circ} 05^{\prime}$ East longitude. Wuhan is one of the hottest cities in China in summer, the study case is the main urban area of Wuhan, including the three towns of Hankou, Wuchang, and Hanyang (Fig. 2). The data in this study are from the building census data of the main urban area of Wuhan in 2010 and the road network (expressway, main road, and secondary trunk road) data of Wuhan in April 2014.

\section{Method and Index Description}

\section{The Method of Ventilation Assessment}

The Ventilation Path Assessment of Urban Street in Wuhan is a combination of geographic information system (GIS) and computational fluid dynamics (CFD). The building data and street data are imported into the geographic information system (GIS) to calculate the morphological index related to the ventilation potential, such as the front area density and street orientation, it abstracts the complex three-dimensional shape of the city onto a two-dimensional plane through grid and line elements. It analyses the attribute data of raster and line features to mine ventilation paths. The ideal threedimensional model has been imported into CFD for simulation calculation, and find the relationship between urban street morphology index (such as street aspect ratio, street length, street orientation) and ventilation potential as the basis of spatial analysis [25].

\section{The Ventilation Index of Urban Buildings}

It is possible to explore a more detailed, accurate, and wide-ranging wind path classification method through the analysis and evaluation of a large number of built environmental data. The evaluation method of urban building ventilation is mainly to project the three-dimensional building environment onto the two-dimensional plane and it was expressed through the spatial resolution of grids. The air velocity of the near-surface layer is mainly affected by the front area density. The spatial analysis technology of GIS was used to calculate the front area density of Wuhan's built environment and the front area density was classified as depicted in Fig. 2. The ventilation paths were divided from the front area density map. The formula for calculating the front area density is as follows:

$$
\lambda_{f(\theta)}=\frac{A_{F}}{A_{T}}=L_{y} Z_{H} \rho_{e l}
$$

Front area density refers to the projected area of a building in a certain direction of wind and flow, and the average wind speed of the built environment has a strong correlation with the front area density [26]. $A_{F}$ represents the area of the building's windward side, and the angle of the wind direction is $\theta$; $A_{T}$ represents the total land area of the building; $\mathrm{L}_{\mathrm{y}}$ represents the average width of the windward roughness object; $Z_{\mathrm{H}}$ represents the average height of the building; $\rho_{\mathrm{el}}$ represents the building density per unit area.

It uses the $100 \mathrm{~m} * 100 \mathrm{~m}$ grids to quantify the front area density that affects ventilation (Fig. 2). The wind tunnel experiment was conducted in 10 regions of Hong Kong. The wind speed ratio (the ratio of the near land surface wind speed and the high altitude initial wind speed) of each region by the several measured points were calculated, and the analysis is the linear regression relationship between the average value and the region of the average front area density under different computing height (height 1: $0 \mathrm{~m}$ to 15 $\mathrm{m}$, height 2: $0 \mathrm{~m}-60 \mathrm{~m}$, height 3: $15 \mathrm{~m}-60 \mathrm{~m})$. We found that the relation between the near-ground layer of 
$0 \mathrm{~m}$ to $15 \mathrm{~m}$ and the ventilation potential was the highest correlation. Wind tunnel experiments have proved that there is a strong negative correlation between the front area density and the wind speed ratio in the near-ground layer (height: 1: $0 \mathrm{~m}-15 \mathrm{~m}$ ). In the Wuhan case study, the natural breakpoint method was used to calculate the height of near the ground, and the height of near the ground was $27 \mathrm{~m}$. We need to calculate the front area that the height of the building is below $27 \mathrm{~m}$.

To provide a scientific basis for the detection of potential and existing urban air paths, we classify the value of the front area density. When the front area density is greater than 0.6 , the wind speed ratio will be less than 0.1 , indicating a poor urban natural ventilation environment. When front area density is less than 0.35 , the wind speed ratio will be greater than 0.2 , indicating an ideal urban natural ventilation environment. The ventilation path has been detected by the building method.

Due to the limitations of grid units, the evaluation of building ventilation based on front area density ignores the ventilation function of streets, which are an important path of urban ventilation. The street orientation, buildings on both sides of the street, and street length mainly affect the ventilation potential of urban streets. When the street is parallel to the prevailing wind direction and the street length is short, the ventilation effect on the street is best. When the direction of the street is perpendicular to the prevailing wind direction and the length of the street is long, the ventilation effect of the street is not ideal due to the shelter of buildings.

\section{The Ventilation Index of Street Orientation and Length}

Computational Fluid Dynamics is a time-saving, low-cost, and accurate method of wind research [27, 28]. In the evaluation of building ventilation, the index of the urban building form is quantified and the weight relationship between each index is determined through Computational Fluid dynamics (CFD) data analysis
[29-31]. For the street ventilation potential evaluation, the index of street morphological can also be extracted to study the quantitative relationship between the street morphological index and ventilation potential. As an important path of urban ventilation, the street conforming to the prevailing wind direction can better improve the ventilation environment of the street.

The ventilation potential is an indicator of wind speed with a height of $1.5 \mathrm{~m}$. In the boundary conditions, the terrain factor $\mathrm{a}=0.14$, and the boundary layer thickness $d=270 \mathrm{~m}$. The block size is $300 \mathrm{~m} \times 340 \mathrm{~m}, 40 \mathrm{~m}$ wide street, gable width of $10 \mathrm{~m}$, the single building is that the lenght is $60 \mathrm{~m}$, the width is $20 \mathrm{~m}$ and the height is $18 \mathrm{~m}$, the initial wind speed is $5 \mathrm{~m} / \mathrm{s}$, the boundary conditions of the dominant wind direction change each $15^{\circ}, 0^{\circ}$ means that the dominant wind direction is parallel to the street, $90^{\circ}$ means that the dominant wind direction is perpendicular to the street (Fig. 3).

After establishing the simulation model and setting the boundary conditions, the computational room is divided into grids (the grid size is one-twentieth of the computational room to guarantee simulation precision and reduce the computation cost) and the calculation model of which the turbulence model is the RNG K - epsilon model which is selected in our research. The number of iterations is more than 500 .

Simulation results show that the ventilation potential of the street decreases with the increase of wind angle. When the angle between the street and the prevailing wind direction is $0^{\circ}$, the wind speed on the street reaches its maximum and is significantly higher than the angle of other wind directions. And the wind speed at the wind path entrance is higher than the wind speed far from the path. As the length of the street is increased, the wind speed of the pedestrian height at the centre of the street is weakening. The wind speed is lowest when the prevailing wind direction is perpendicular to the street (Fig. 3).

It can be found that when the prevailing wind direction is parallel to the urban road, the wind on the street will suffer the least resistance. Meanwhile, the

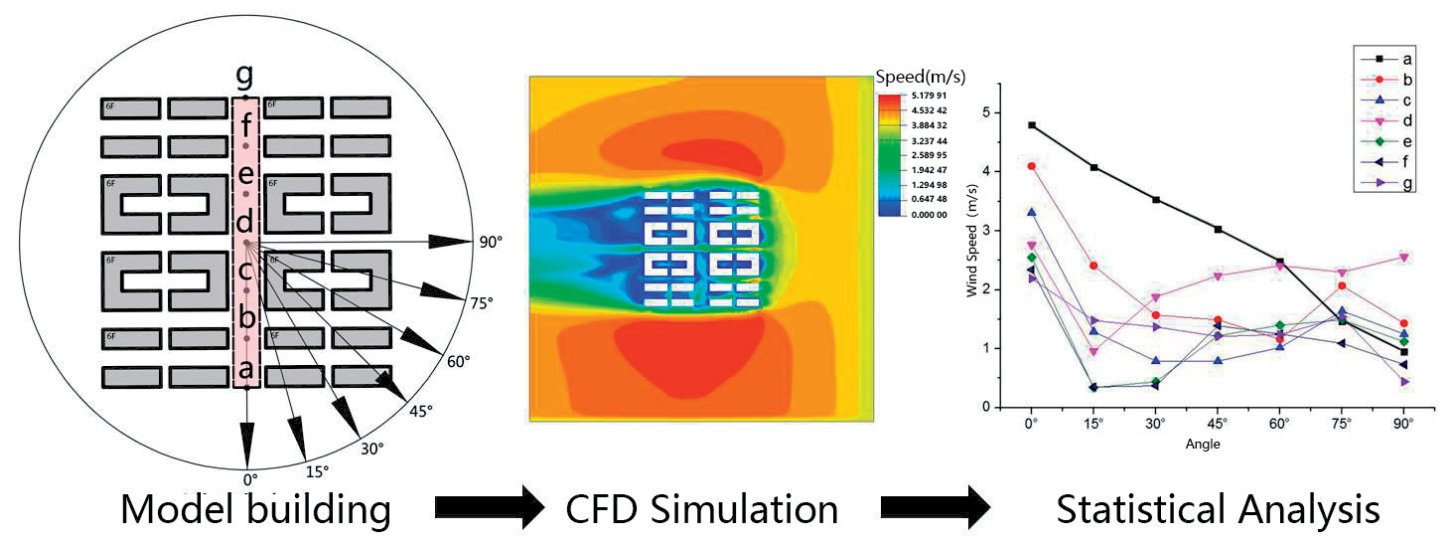

Fig. 3. The schematic diagram for simulation and analysis of street ventilation potential. 


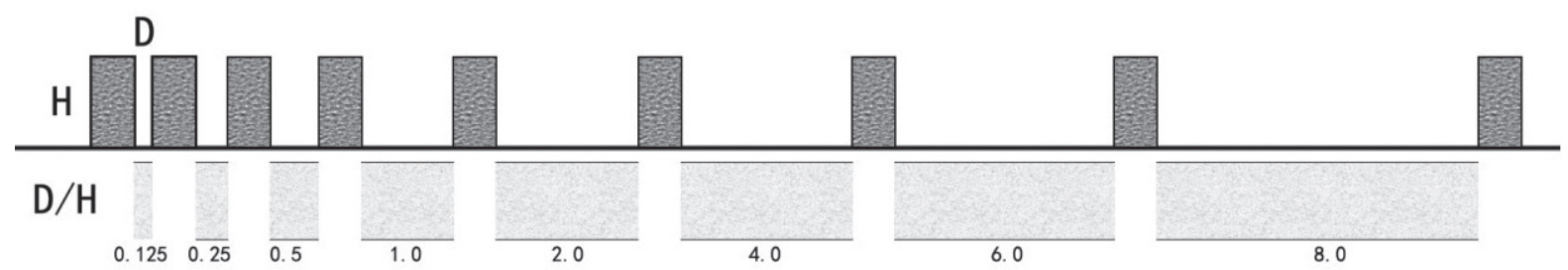

Fig. 4. Distribution of Street Aspect Ratio.

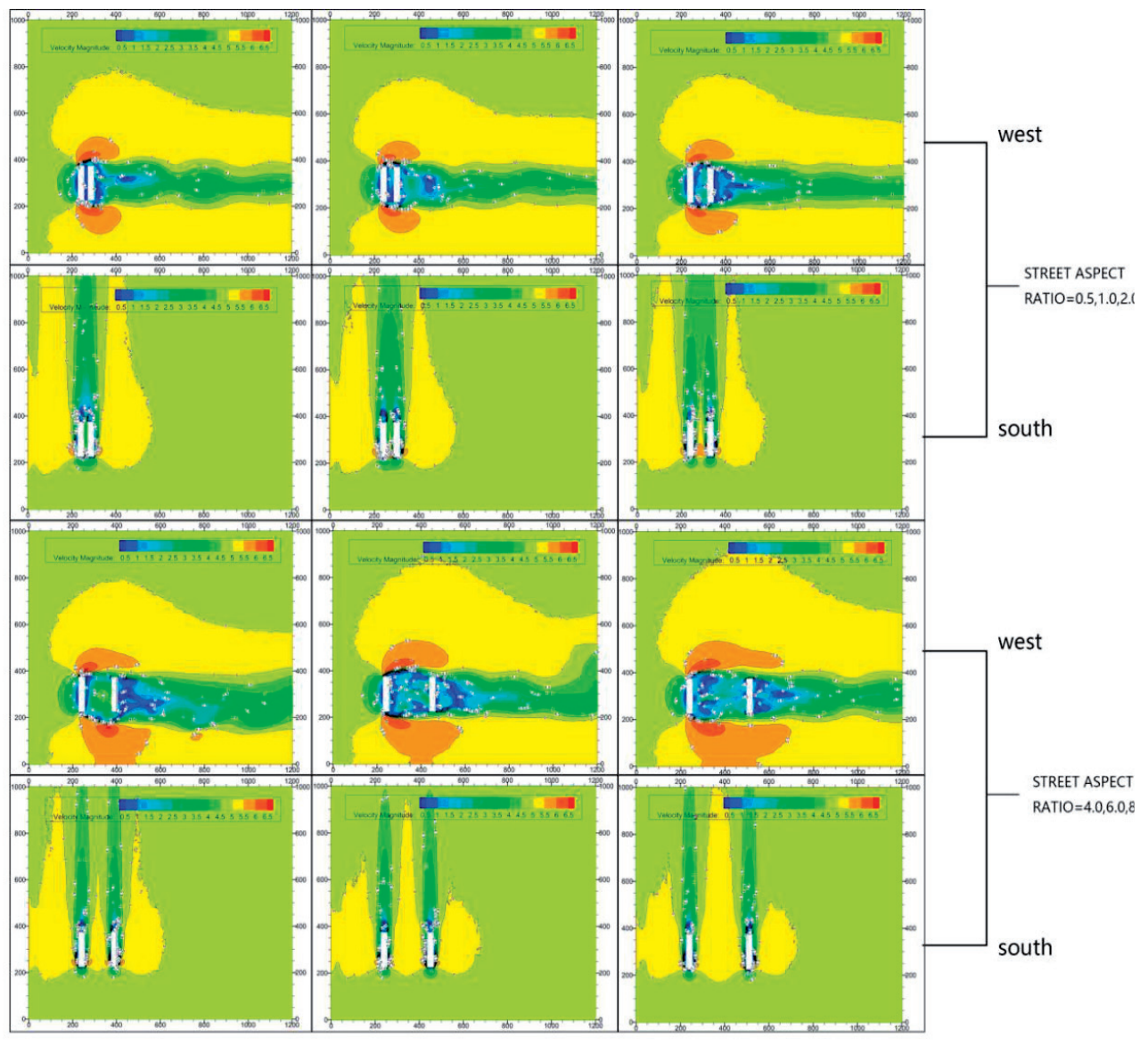

a) Wind Speed Map of Pedestrian

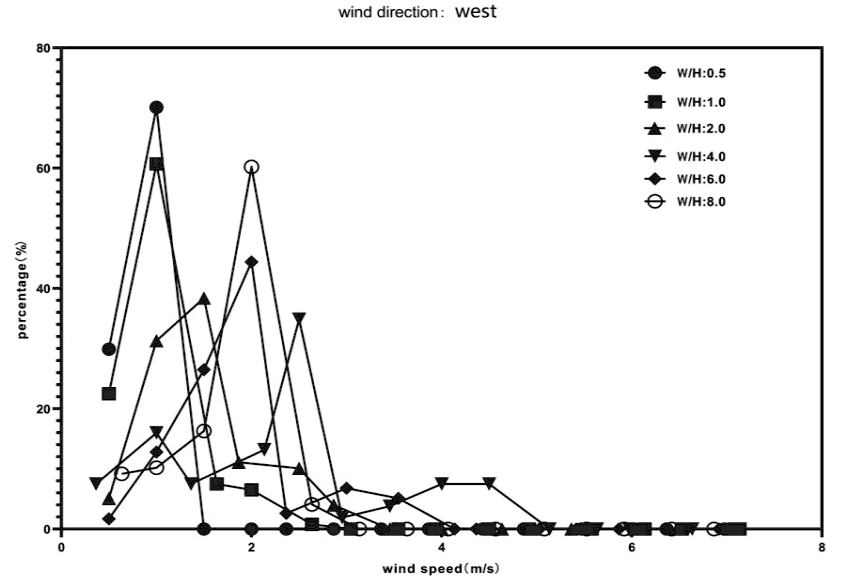

b) Wind Speed Distribution of West

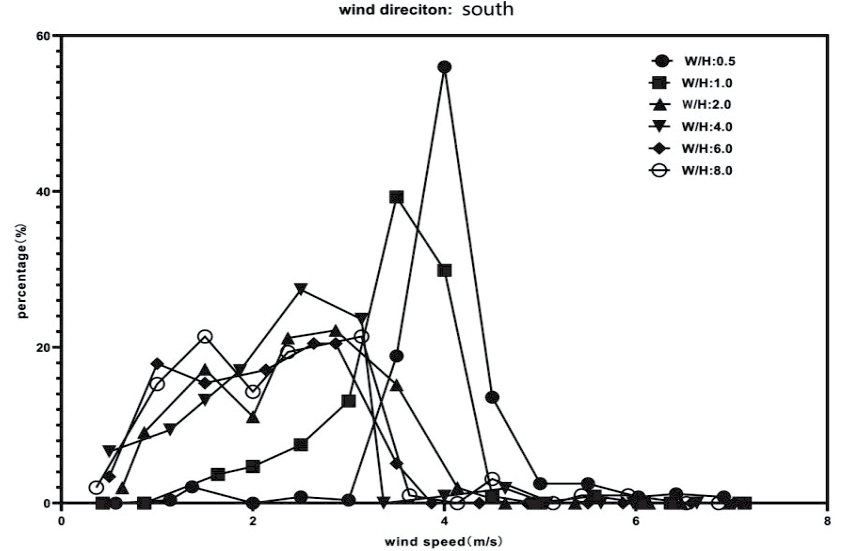

c) Wind Speed Distribution of South

Fig. 5. Distribution of ventilation levels in different wind directions: a) Wind Speed Map of Pedestrian; b) Wind Speed distribution of West; c) Wind Speed distribution of South. 
Table 1. Street ventilation parameters with different street aspect ratios.

\begin{tabular}{|c|c|c|c|c|c|c|c|c|}
\hline \multirow{2}{*}{ W/H } & \multicolumn{4}{|c|}{ Wind direction: west $(\mathrm{m} / \mathrm{s})$} & \multicolumn{4}{c|}{ Wind direction: south (m/s) } \\
\cline { 2 - 9 } & Min & Max & Mean & Standard Deviation & Min & Max & Mean & Standard Deviation \\
\hline 0.5 & 0.13 & 0.95 & 0.57 & 0.2456 & 0.94 & 6.66 & 3.74 & 0.7296 \\
\hline 1.0 & 0.07 & 1.99 & 0.76 & 0.3690 & 1.27 & 5.19 & 3.13 & 0.6658 \\
\hline 2.0 & 0.34 & 2.70 & 1.28 & 0.5781 & 0.29 & 3.69 & 2.13 & 0.8471 \\
\hline 4.0 & 0.28 & 4.39 & 2.04 & 1.0984 & 0.22 & 4.05 & 1.96 & 0.8476 \\
\hline 6.0 & 0.32 & 3.25 & 1.63 & 0.6241 & 0.38 & 3.28 & 1.82 & 0.8005 \\
\hline 8.0 & 0.31 & 2.38 & 1.41 & 0.4846 & 0.45 & 5.57 & 1.95 & 0.9811 \\
\hline
\end{tabular}

buildings on both sides of the street will accelerate the air velocity and have the best ventilation effect. When the prevailing wind direction is perpendicular to the city street, the airflow passes above the building or within the space between the buildings. The airflow on the street is colliding with the buildings on both sides of the street and the airflow speed is lowest. When the prevailing wind direction is at an angle with the urban road, the street ventilation effect is between the two situations. Therefore, street orientation is an important index for evaluating the ventilation potential of streets, and the angle relationship between street and prevailing wind direction is calculated in the Geographic Information System (GIS).

\section{The Ventilation Index of Street Aspect Ratio}

The street aspect ratio is a significant index of ventilation potential (Fig. 4). However, the different street aspect ratio will produce a different ventilation result and mechanism when the wind direction is vertical or parallel to the long street axis:

(1) If the wind direction is perpendicular to the street (Fig. 5a), the airflow blows over the street. Due to the windward buildings, the airflow cannot blow to the surface ground, it blows to the back of the leeward building. With the increase of street aspect ratio and street width, the leeward building obstructs the airflow and blows to the surface ground, and the street ventilation potential is increasing;

(2) If the wind direction is parallel to the street (Fig. 5a), airflow is due to the drive effect on both sides of the street buildings that the airspeed will increase. The smaller the street aspect ratio is, the higher the wind speed is.

The two street wind mechanisms were taken into the assessment of street ventilation potential. Even if the aspect ratio is the same, the ventilation capacity of streets under different direction winds is still significantly different. The ideal street models with different aspect ratios $(\mathrm{W} / \mathrm{H})$ which were $0.5,1.0,2.0$, 4.0, 6.0, and 8.0 respectively (Fig. 4, Fig. 5a), Table 1), The formula for calculating the street aspect ratio is as follows:

$$
R_{(W / H)}=\frac{W_{\text {Street }}}{H_{\text {Street }}}
$$

$\mathrm{R}_{(\mathrm{W} / \mathrm{H})}$ is the street aspect ratio, $\mathrm{W}_{\text {Street }}$ is the width of the street, $\mathrm{H}_{\text {Street }}$ is the building height along the street. There are two ventilation mechanisms:

(1) When the wind direction is perpendicular to the long axis of the street and the aspect ratio $(\mathrm{W} / \mathrm{H})$ is 8.0, the ventilation degree of pedestrian height on the street is the best. When the aspect ratio $(\mathrm{W} / \mathrm{H})$ is 0.5 , the ventilation degree of pedestrian height on the street is the lowest, and with the increasing of the aspect ratio, the ventilation potential increases gradually. The vortex airflow phenomenon will occur on the street. When the aspect ratio $(\mathrm{W} / \mathrm{H})$ of the street is less than 2.0, the airflow does not enter the street and flow passes over the roof of the building. The average wind speed of the pedestrian height on the street is relatively low. When the street aspect ratio $(\mathrm{W} / \mathrm{H})$ of the street is equal to 8.0, the wake flow of the buildings in the front row is blowing to the ground by the shielding of the buildings in the back row and the average wind speed of the pedestrian height on the street is relatively higher (Fig. 5b).

(2) When the wind direction is parallel to the street, the ventilation potential of pedestrian height on the street is also affected by the street aspect ratio but the opposite is true. When the aspect ratio $(\mathrm{W} / \mathrm{H})$ is 0.5 , the ventilation degree of pedestrian height on the street is the best; when the aspect ratio $(\mathrm{W} / \mathrm{H})$ is 8.0 , the ventilation degree of pedestrian height on the street is the lowest. Moreover, with the increasing of street aspect ratio $(\mathrm{W} / \mathrm{H})$, the ventilation potential gradually weakens. Buildings on each side of the street create a drive effect on the air to increase its speed. When the street aspect ratio $(\mathrm{W} / \mathrm{H})$ is equal to 0.5 , the drive effect of buildings on both sides of the street is the strongest, the air pressure at the entrance of the air path is the highest and the air velocity reaches $6.5 \mathrm{~m} / \mathrm{s}$. When the street aspect ratio $(\mathrm{W} / \mathrm{H})$ is equal to 8.0 , the drive effect on both sides of the street is the weakest, the airflow pressure at the entrance of the air path is the lowest, and the average wind speed is the lowest (Fig. 5c). 
a)

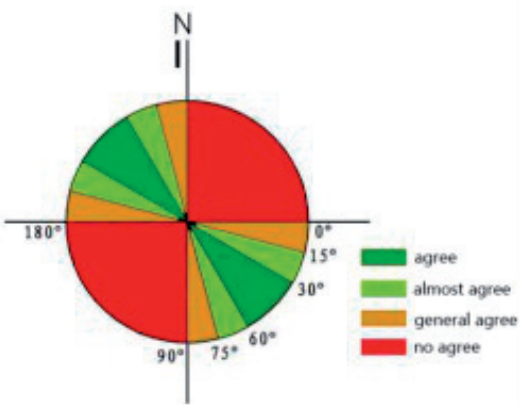

b)

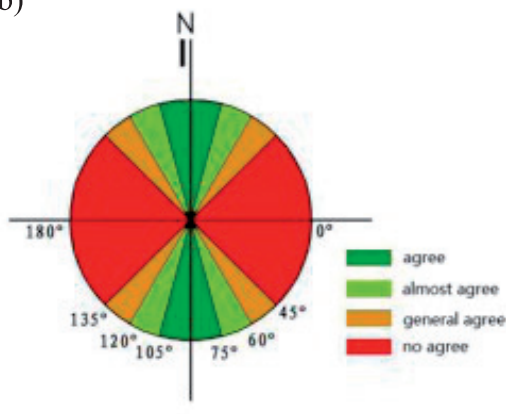

c)

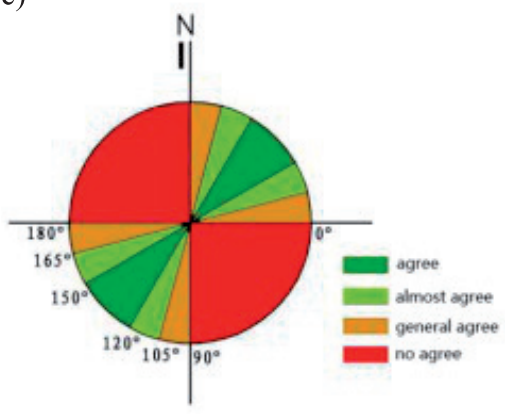

Fig. 6. Schematic Diagram: a) Southeast; b) South; c) Southwest.

\section{Results and Discussion}

\section{GIS Analysis Result and Discussion}

The pedestrian wind environment in a street canyon is affected by the height and geometric shape of the surrounding buildings, the street width, and the wind direction [32], The combination of Geographic Information System (GIS) and Computational Fluid dynamics (CFD) can improve the efficiency and accuracy of urban wind environment simulation [33], the abbreviation of Geographic Information System and Computational Fluid dynamics is GIS and CFD respectively. Based on the Computational Fluid

Table 2. Comprehensive grading table of roads at all levels.

\begin{tabular}{|c|c|c|c|}
\hline \multicolumn{4}{|c|}{ The score of street orientation } \\
\hline Wind Direction & The direction angle of the road & Evaluation & Score \\
\hline \multirow{4}{*}{ South East } & $90^{\circ} \sim 180^{\circ}$ & No agree & 0 \\
\hline & $0^{\circ} \sim 15^{\circ}$ or $75^{\circ} \sim 90^{\circ}$ & General agree & 1 \\
\hline & $15^{\circ} \sim 30^{\circ}$ or $60^{\circ} \sim 75^{\circ}$ & Almost agree & 2 \\
\hline & $30^{\circ} \sim 60^{\circ}$ & Agree & 3 \\
\hline \multirow{4}{*}{ South } & $0^{\circ} \sim 45^{\circ}$ or $135^{\circ} \sim 180^{\circ}$ & No agree & 0 \\
\hline & $45^{\circ} \sim 60^{\circ}$ or $120^{\circ} \sim 135^{\circ}$ & General agree & 1 \\
\hline & $60^{\circ} \sim 75^{\circ}$ or $105^{\circ} \sim 120^{\circ}$ & Almost agree & 2 \\
\hline & $75^{\circ} \sim 105^{\circ}$ & Agree & 3 \\
\hline \multirow{4}{*}{ South West } & $0^{\circ} \sim 90^{\circ}$ & no agree & 0 \\
\hline & $90^{\circ} \sim 105^{\circ}$ or $165^{\circ} \sim 180^{\circ}$ & general agree & 1 \\
\hline & $105^{\circ} \sim 120^{\circ}$ or $150^{\circ} \sim 165^{\circ}$ & almost agree & 2 \\
\hline & $120^{\circ} \sim 150^{\circ}$ & agree & 3 \\
\hline \multicolumn{4}{|c|}{ The attenuation coefficient of street length and front area density } \\
\hline Length (m) & FAD & \multicolumn{2}{|c|}{ Coefficient } \\
\hline Length $<100$ & $\mathrm{FAD}<0.35$ & \multicolumn{2}{|c|}{1.0} \\
\hline $100 \leq$ Length $<300$ & $0.35 \leq \mathrm{FAD}<0.45$ & \multicolumn{2}{|c|}{0.8} \\
\hline $300 \leq$ Length $<1000$ & $0.45 \leq \mathrm{FAD}<0.6$ & \multicolumn{2}{|c|}{0.6} \\
\hline Length $\geq 1000$ & $\mathrm{FAD} \geq 0.6$ & \multicolumn{2}{|c|}{0.4} \\
\hline \multicolumn{4}{|c|}{ Variation coefficient of street aspect ratio } \\
\hline Aspect ratio $(\mathrm{W} / \mathrm{H})$ & \multicolumn{3}{|c|}{$\begin{array}{ll}\text { Coefficient } \\
\end{array}$} \\
\hline $0.0 \sim 0.5$ & \multicolumn{3}{|c|}{0.80} \\
\hline $0.5 \sim 1.0$ & \multicolumn{3}{|c|}{0.60} \\
\hline $1.0 \sim 2.0$ & \multicolumn{3}{|c|}{0.40} \\
\hline $2.0 \sim 4.0$ & \multicolumn{3}{|c|}{0.20} \\
\hline $4.0 \sim 6.0$ & \multicolumn{3}{|c|}{0.10} \\
\hline
\end{tabular}


dynamics (CFD) numerical simulation analysis, it can be found that the ventilation potential of streets is mainly relating to the street orientation, street length, street aspect ratio, and the front area density of buildings on both sides of streets: (1) the more the street orientation conforms to the prevailing wind direction, the higher the ventilation potential is; (2) the lower the front area density of buildings on both sides of the street, the higher the ventilation potential is; (3) the longer the length of the street is, the lower the ventilation potential is; (4) when the wind direction is parallel to the street, the smaller the aspect ratio is, the higher the ventilation potential is; when the wind direction is perpendicular to the street, the higher the aspect ratio is, the higher the ventilation potential is.

The front area density, street length, street aspect ratio, and urban street orientation were quantified in the Geographic Information System (GIS). The angle between the direction of the streets (expressway, main road, and secondary main road) and the prevailing wind direction was calculated in GIS. The length of the streets was reclassified into some new levels in the evaluation process of ventilation potential. The street buffer width is $250 \mathrm{~m}$ through the GIS buffer analysis, it is to reach the average front area density of each street (the front area density is single directional).

The further quantification of street orientation is used by the Spatial Analysis Technology of GIS, the threshold value of the angle between the street and prevailing wind direction was defined to distinguish good ventilation and poor ventilation, and the standard takes $15^{\circ}$ as the variation value. If the angle between the street and the prevailing wind direction exceeds $45^{\circ}$, the ventilation potential decreases sharply. If the angle between the street and the prevailing wind direction is less than $30^{\circ}$, the ventilation potential of the street is higher. The ventilation potential of streets is best when the angle between streets and prevailing wind direction is less than $15^{\circ}$. In the Geographic Information System (GIS), the ventilation potential of streets has been divided into four categories. Based on the boundary conditions of the dominant wind direction (southeast, south, and southwest) in Wuhan during the summer, the criteria of street orientation has been established that the west direction was $180^{\circ}$, the south direction was $90^{\circ}$ and the east direction was $0^{\circ}$ (Fig. 6, Table 2).

Taking the summer southerly prevailing wind direction for example (Fig. 6b), the urban road system is divided into four levels which $90^{\circ}$ is the south. The consistency of road orientation and prevailing wind direction is four situations:

(1) When the angle between road orientation and the horizontal axis is $75^{\circ} \sim 105^{\circ}$, the angle between the street direction and prevailing wind direction is less than $15^{\circ}$ and the ventilation effect is the best;

(2) When the angle between road orientation and the horizontal axis is $60^{\circ} \sim 75^{\circ}$ or $105^{\circ} \sim 120^{\circ}$, the angle between the street direction and prevailing wind direction is $15^{\circ}$ to $30^{\circ}$, and the ventilation effect is better;

(3) When the angle between road orientation and the horizontal axis is $45^{\circ} \sim 60^{\circ}$ or $120^{\circ} \sim 135^{\circ}$, the angle between the street direction and prevailing wind direction is $30^{\circ}$ to $45^{\circ}$, and the ventilation effect is good;

(4) When the angle between road orientation and the horizontal axis is $0^{\circ} \sim 45^{\circ}$ or $135^{\circ} \sim 180^{\circ}$, the angle between the street direction and prevailing wind direction is $45^{\circ}$ to $90^{\circ}$, and the ventilation effect is poor.

The consistency degree between the street direction and the prevailing wind direction has been scored. Due to the road being able to meet the ventilation requirements of multiple dominant wind directions at the same time, we can plus the potential value of a single direction score in the ventilation potential assessment. The assessment considers the attenuation of street length and the attenuation of front area density to obtain the comprehensive score of streets (Table 2). The road widths of an expressway, main road, and secondary main road are $50 \mathrm{~m}, 40 \mathrm{~m}$, and $30 \mathrm{~m}$ respectively to calculate the street aspect ratio. The street buffer width is $250 \mathrm{~m}$ which the average building height inside the buffer zone is counted. The ratio of height to width is the ratio between street width and average building height (Table 2).

If the wind direction is parallel to the street, the lower street aspect ratio will improve the ventilation speed, while the wind direction is perpendicular to the street, the lower aspect ratio will weaken the ventilation speed. When the angle between the street direction and the prevailing wind direction is $45^{\circ}$, the street aspect ratio attenuation coefficient is reduced by half. If the street is not parallel or perpendicular to the prevailing wind direction, the street orientation, the front area density, and street length mainly affect ventilation. Therefore, the ventilation evaluation formula is as follow:

$$
\begin{gathered}
\text { If } \mu_{\mathrm{es}}=3, \quad W=\left[\mu_{\mathrm{es}}\left(1+\beta_{W / H}\right) \mathrm{FAD}_{\mathrm{es}}+\mu_{s}\left(1-0.5 \beta_{W / H}\right) \mathrm{FAD}_{s}+\right. \\
\left.\mu_{\mathrm{ws}}\left(1-\beta_{W / H}\right) \mathrm{FAD}_{\mathrm{ws}}\right] \mu_{\text {length }}
\end{gathered}
$$

$$
\begin{aligned}
\text { If } \mu_{s}=3, W= & {\left[\mu_{\mathrm{es}}\left(1-0.5 \beta_{W / H}\right) \mathrm{FAD}_{\mathrm{es}}+\mu_{s}\left(1+\beta_{W / H}\right) \mathrm{FAD}_{s}+\right.} \\
& \left.\mu_{\mathrm{ws}}\left(1-0.5 \beta_{W / H}\right) \mathrm{FAD}_{\mathrm{ws}}\right] \mu_{\text {length }}
\end{aligned}
$$

$$
\begin{gathered}
\text { If } \mu_{\mathrm{ws}}=3, W=\left[\mu_{\mathrm{es}}\left(1-\beta_{W / H}\right) \mathrm{FAD}_{\mathrm{es}}+\mu_{s}\left(1-0.5 \beta_{W / H}\right) \mathrm{FAD}_{s}+\right. \\
\left.\mu_{\mathrm{ws}}\left(1+\beta_{W / H}\right) \mathrm{FAD}_{\mathrm{ws}}\right] \mu_{\text {length }}
\end{gathered}
$$

$$
\begin{gathered}
\text { If } \mu_{\mathrm{es}}<3 \text { and } \mu_{s}<3 \text { and } \mu_{\mathrm{ws}}<3, \\
W=\left(\mu_{\mathrm{es}} \mathrm{FAD}_{\mathrm{es}}+\mu_{s} \mathrm{FAD}_{s}+\mu_{\mathrm{ws}} \mathrm{FAD}_{\mathrm{ws}}\right) \mu_{\text {length }}
\end{gathered}
$$

The comprehensive evaluation value $W$ is equal 

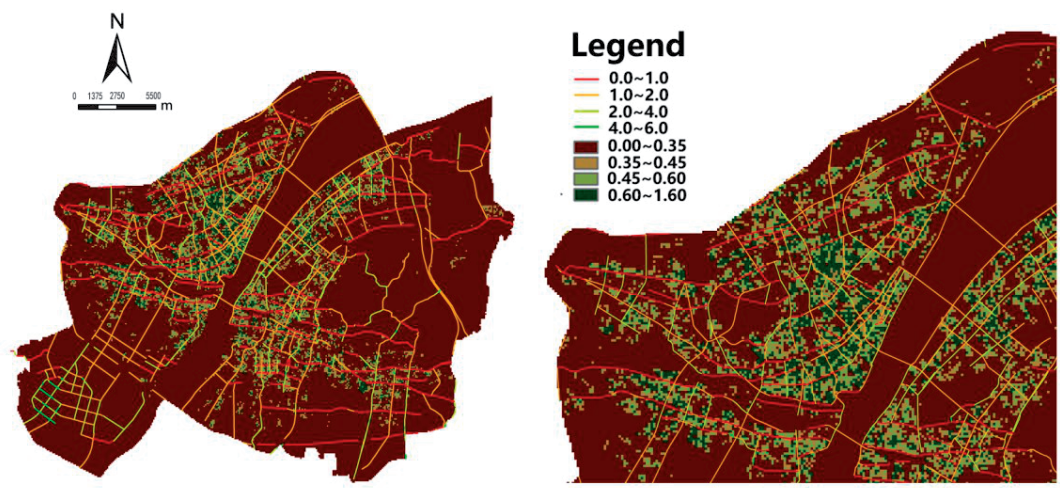

a) GIS evaluation map of the main urban area

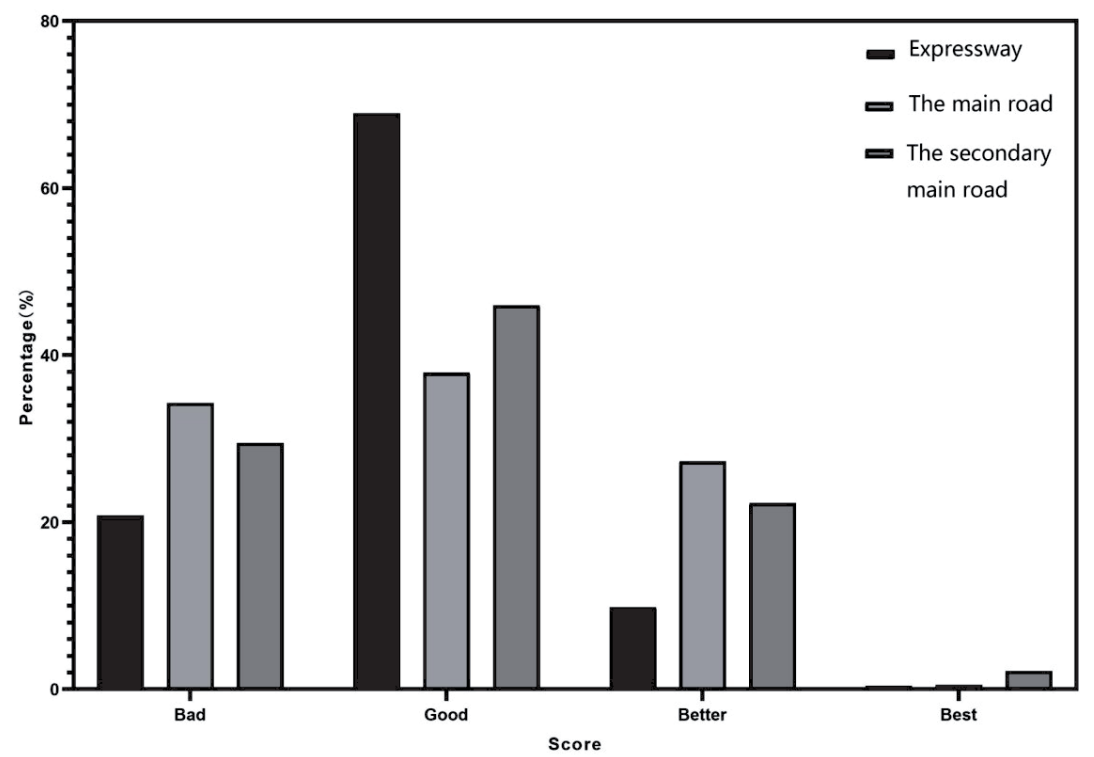

b) Statistics of current road ventilation degree

Fig. 7. Statistics result of current road ventilation in the main urban area: a) GIS evaluation map of the main urban area; b) Statistics of current road ventilation degree.

to the sum of the scores under the dominant wind direction, $\mu$ is the score under the southeast, southwest, and south wind, $\mu_{\text {lenght }}$ is the attenuation coefficient of the street length, $\beta_{W H}$ is the attenuation coefficient of aspect ratio. If the comprehensive evaluation value is greater than 4 and less than 6 , it indicates that the street ventilation degree is the best. If the comprehensive evaluation value is greater than 2 and less than 4, it indicates that the street ventilation is better. If the comprehensive evaluation value is greater than 1 and less than 2, it indicates that the street ventilation is good. If the comprehensive evaluation value is less than 1 , it indicates poor street ventilation.

The assessment of the street system in the main urban area can help planners to dig out poorly ventilated streets and improve them with planning strategies. In the comprehensive assessment of Wuhan's current roads (Fig. 7(a-b)), the secondary main road length of the best ventilation has the highest proportion, accounting for $2.2 \%$, and $27.3 \%$ of the main road length is the better ventilation. The proportion of expressway length in good ventilation reaches $69.0 \%$. The proportion of roads in poor ventilation is the same among all road types, keeping at about $30 \%$. We found that the main road network system in Wuhan has the best ventilation adaptability.

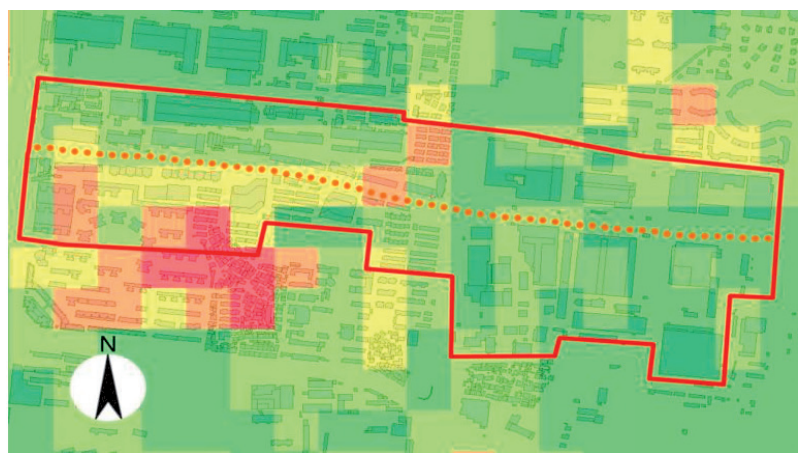

Fig. 8. The distribution of Front Area Density. 


\section{CFD Analysis Result and Discussion}

The ventilation effect can be enhanced by improving the building form along the street [34], The spatial layout of buildings plays a decisive role in the performance of ventilation [35]. It uses CFD simulation technology for further study. The Wuhan Optics Valley Street has been selected as the simulation object where its total length is about $1800 \mathrm{~m}$ (Fig. 8). The street location is at the edge of Wuhan city center, surrounded by Huazhong University of Science and Technology. The land type on both sides of the street is mainly residential, commercial, and industrial, and the direction of the street is east-west, which is inconsistent with the dominant wind direction (southeast, southwest, and south direction) in summer. The score by the southeast dominant wind direction is 1.0 (the angle with the southeast wind direction is $0^{\circ} \sim 15^{\circ}$ or $75^{\circ} \sim 90^{\circ}$ ).
The simulation calculation generates a wind speed map at $1.5 \mathrm{~m}$ height as the planning and the current situation (Fig. 9(a-b)). The wind speed node data is for the comparative analysis between the planning and the current ventilation (Fig. 9c). Some specific planning measures are proposed to improve the ventilation.

(1) In the east end area of the street, there are a large number of industrial buildings with less than three floors. The single building has a large volume, occupies a relatively large area, and has a compact layout. The planning measures will reduce the area occupied by individual buildings, reduce the building density, and transform them into small-volume factory buildings through form segmentation. Enough space will be left between the factory buildings to guide the air into the interior of the plot.

(2) There are many residential and commercial buildings in the west, building form is point and slab,

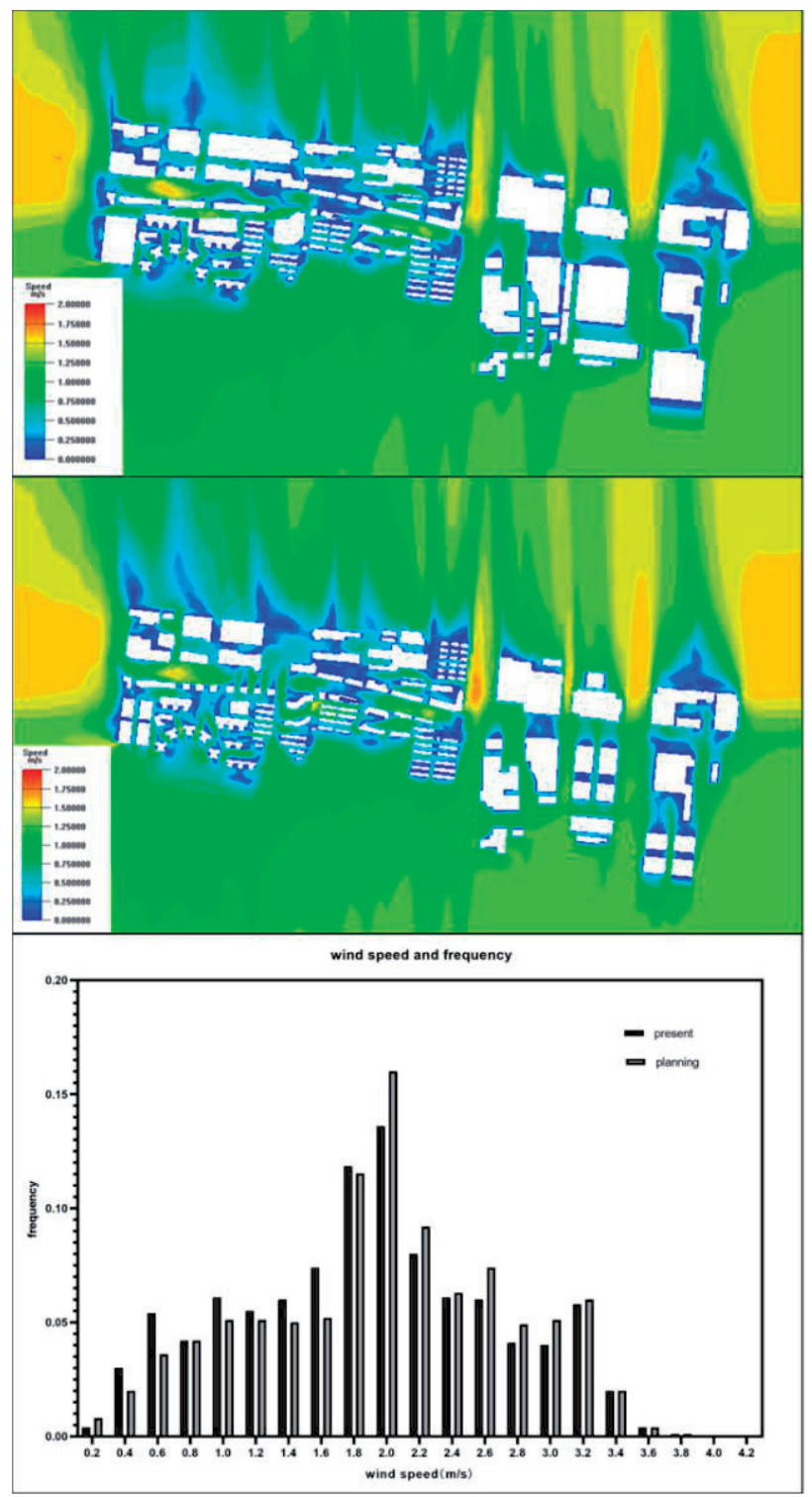

a) The current ventilation

b) The planning ventilation

\section{c) Comparison between the} current situation and planned situation

Fig. 9. Comparison between the current situation and wind speed frequency under $3 \mathrm{~m}$ in the planned block (South wind): a) the current ventilation; b) the planning ventilation; c) Comparison between the current situation and planned situation. 
the building height is tall. The pointed building is helpful for ventilation, but the podium of the point building will block the airflow at the pedestrian level, so the planning measures are to reduce the length of the podium and interrupt the surface of a high-rise building with organization air circulation path.

(3) The street is perpendicular to the prevailing wind direction and street length is longer, the front area of buildings along the street has an important effect on internal blocks ventilation, the planning measures are to shorten the length of buildings along the street, reduce the front area density of the buildings along the street, get through the ventilation path of perpendicular to the street and increase the air permeability of the street.

Through the microcosmic simulation of the prevailing south wind direction during summer in the block, the wind speed frequency of the wind speed node below $3 \mathrm{~m}$ in the block is calculated. The minimum wind speed of the current block is $0.02 \mathrm{~m} / \mathrm{s}$, the maximum wind speed is $4.07 \mathrm{~m} / \mathrm{s}$ and the average wind speed is $1.83 \mathrm{~m} / \mathrm{s}$. After the building form of the block is improved through planning measures, the minimum wind speed of the planned block is $0.03 \mathrm{~m} / \mathrm{s}$, the maximum wind speed is $3.97 \mathrm{~m} / \mathrm{s}$ and the average wind speed is $1.88 \mathrm{~m} / \mathrm{s}$. The overall ventilation level of the planned block is stronger than that of the current block. Frequency statistics of wind speed nodes are given (Fig 9c) and the frequency of wind speed in blocks between $2.0 \mathrm{~m} / \mathrm{s}$ and $3.2 \mathrm{~m} / \mathrm{s}$ is higher than the current situation, while the frequency of wind speed between $0.0 \mathrm{~m} / \mathrm{s}$ and $1.8 \mathrm{~m} / \mathrm{s}$ is lower than the current situation, therefore the wind speed is enhanced.

The simulation is based on an ideal street model. In an actual urban environment, the ventilation situation may be more complicated, and the influencing factors are dynamic and changeable, which has a limitation, but the present findings suggest a preliminary method to build up a correlation between street morphology parameters and ventilation efficiency to evaluate all the city for urban planners. It has combined the Geographic Information System and Computational Fluid dynamics simulation as a reference for street ventilation assessment.

In the future, the accuracy of evaluation results needs to be further enhanced, it can use the weather research and forecast model (WRF) simulation to generate urban local wind field data, and the generated data is to fit the weather station's wind speed and direction data, it can find the potential street ventilation path, and the potential street ventilation path can contrast to the assessed results, it can be tested and improved.

\section{Conclusions}

The building ventilation method is based on building front area density, while this method ignores the ventilation path of urban streets; the study is the supplement of the street ventilation assessment. The methods of GIS and CFD numerical simulation are used interactively. The street form is transforming into street orientation, the street length, aspect ratio, and front area density of buildings beside the street.

The direction of the street is the main assessed index to extract the street ventilation path. Under different wind directions including the vertical and parallel to the street, the street ventilation potential is different as to the street aspect ratio, if the wind direction is parallel to the street, the street ventilation is better with the decrease of street aspect ratio; if the wind direction is perpendicular to the street, the street ventilation is better with the increase of the street aspect ratio. In areas with high front area density, a road parallel to the prevailing wind direction can still guide the air freely. The optimization of spatial form is proposed through windward face, street length, width, height, and street orientation. The optimization of street morphology can improve air circulation.

\section{Acknowledgements}

This study was conducted with the technical support of the National Natural Science Foundation of China and Funding for post-doctoral work by department of human resources and social security of Hubei Province. I would also like to offer deep thanks to Qingming Zhan from Wuhan University for their assistance in the successful completion of the work. All authors Jie Yin, Muhammad Tayyab and Qingming Zhan have contributed equally to this paper.

\section{Conflict of Interest}

The authors declare no conflict of interest.

\section{References}

1. LI ZHIGANG, XIE CHANGKUN, CHEN DAN, LU HONGYU, CHE SHENGQUAN Effects of Land Cover Patterns on Land Surface Temperatures Associated with Land Use Types along Urbanization Gradients in Shanghai, China. Polish Journal of Environmental Studies, 29 (1), 713, 2020.

2. CAIQING ZHANG, YILIN XU Planning and Policy of Renewable Energy Utilization in a Rural Economic Development Zone. Polish Journal of Environmental Studies, 29 (5), 3915, 2020.

3. CHUNLIN LI, YANYAN XU, MIAO LIU, YUANMAN HU, NA HUANG, WEN WU Modeling the Impact of Urban Three-Dimensional Expansion on Atmospheric Environmental Conditions in an Old Industrial District: A Case Study in Shenyang, China. Polish Journal of Environmental Studies, 29 (5), 3171, 2020.

4. HAMED BIGLARI, SAHAR GERAVANDI, MOHAMMAD JAVAD MOHAMMADI, ELAHEH JAME PORAZMEY, ROZALINA ZLATEVA 
CHUTURKOVA, YUSEF OMIDI KHANIABADI, GHOLAMREZA GOUDARZI, MOHAMMAD MAHBOUBI, BASIR MOHAMMADI, AHMAD REZA YARI Relationship between air particulate matter \& meteorological parameters. Fresenius Environmental Bulletin, 26 (6), 4047, 2017.

5. FARHADI MAJID, SICARD PIERRE, DE MARCO ALESSANDRA, KHOSHGOFTAR MOHAMMAD, TAIWO ADEWALE M., MOHAMMADI MOHAMMAD JAVAD, SADEGHI SHAHRAM, ESMAEILI SHIRIN, AMRANE ABDELTIF, KAMAREHIE BAHRAM, KHANIABADI YUSEF OMIDI Hot spots of nox emission from the cement factory main stacks. Fresenius Environmental Bulletin, 26(12), 730, 2017.

6. CZARNECKA M., NIDZGORSKA-LENCEWICZ J. Intensity of urban heat island and air quality in Gdansk during 2010 heat wave. Polish Journal of Environmental Studies, 23 (2), 329, 2014.

7. QINGMING ZHAN, YULI FAN, YINGHUI XIAO, WANLU OUYANG, YULIANG LAN, ZHICHENG JIN, JIEYIN, LI ZHANG Sustainable Strategy: Comprehensive Computational Approach for Wind Path Planning in Dense Urban Area. International Review for Spatial Planning and Sustainable Development, 6 (4), 148, 2018.

8. MAN SING WONG, JANET E. NICHOL, PUI HANG TO, JINGZHI WANG A simple method for designation of urban ventilation corridors and its application to urban heat island analysis. Building and Environment, 45, 1880, 2010.

9. YULIANG LAN, QINGMING ZHAN How do urban buildings impact summer air temperature? The effects of building configurations in space and time. Building and Environment, 125, 88, 2017.

10. QINGMING ZHAN, SIHANG GAO, YINGHUI XIAO, CHEN YANG, YIHAN WU, ZHIYU FAN, JIAQI WU, MENG ZHAN Impact Mechanism and Improvement Strategy on Urban Ventilation, Urban Heat Island and Urban Pollution Island: A Case Study in Xiangyang, China. International Review for Spatial Planning and Sustainable Development, 8 (3), 68, 2020.

11. KANGKANG GU, YUNHAO FANG, ZHAO QIAN, ZHEN SUN, AI WANG Spatial planning for urban ventilation corridors by urban climatology. Ecosystem Health and Sustainability, 6, 22, 2020.

12. EDWARD NG Policies and technical guidelines for urban planning of high-density cities - air ventilation assessment (AVA) of Hong Kong. Building and Environment, 44, 1478, 2009.

13. WEIWEN WANG, TUSHI YANG, YANNI LI, YUEPENG XU, MING CHANG, XUEMEI WAND Identification of pedestrian-level ventilation corridors in downtown Beijing using large-eddy simulations. Building and Environment, 182, 107169, 2020.

14. XIE PENG, LIU DIANFENG, LIU YANFANG, LIU YAOLIN A Least Cumulative Ventilation Cost Method for Urban Ventilation Environment Analysis. Complexity, 2020.

15. PENG XIE, JUN YANG, HUIYING WANG, YANFANG LIU, YAOLIN LIU A New Method of Simulating Urban Ventilation Corridors Using Circuit Theory. Sustainable Cities and Society, 59, 102162, 2020.

16. CHUN-MING HSIEH, HSIN-CHIAO HUANG Mitigating urban heat islands: A method to identify potential wind corridor for cooling and ventilation. Computers Environment and Urban Systems, 57, 130, 2016.
17. GAL T., UNGER J. Detection of ventilation paths using high-resolution roughness parameter mapping in a large urban area. Building and Environment, 44, 198, 2009.

18. RAN WANG, CHAO REN, YONG XU, KEVIN KA-LUN LAU, YUAN SHI Mapping the local climate zones of urban areas by GIS-based and WUDAPT methods: A case study of Hong Kong. Urban Climate, 24, 567, 2018.

19. MAIDER LLAGUNO-MUNITXA, ELIE BOU-ZEID Shaping buildings to promote street ventilation: A largeeddy simulation study. Urban Climate, 26, 76, 2018.

20. LI BIAO, JIANG CUNYAN, WANG LU, CAI WEIHUA, LIU JING A parametric study of the effect of building layout on wind flow over an urban area. Building and Environment, 160, 106160, 2019.

21. ZHI QIAO, XINLIANG XU, FENG WU, WEN LUO, FANG WANG, LUO LIU, ZONGYAO SUN Urban ventilation network model: A case study of the core zone of capital function in Beijing metropolitan area. Journal of Cleaner Production, 168, 526, 2017.

22. YU-CHENG CHEN, TZU-PING LIN, CHIEN-TING LIN A simple approach for the development of urban climatic maps based on the urban characteristics in Tainan, Taiwan. International Journal of Biometeorology, 61, 1029, 2017.

23. SHOUZHI CHANG, QIGANG JIANG, YING ZHAO Integrating CFD and GIS into the Development of Urban Ventilation Corridors: A Case Study in Changchun City, China. Sustainability, 10, 1814, 2018.

24. CHAO REN, RUOZI YANG, CHEN CHENG, PEI XING, XIAOYI FANG, SHUO ZHANG, HUIFANG WANG, YUAN SHI, XUYI ZHANG, YU TING KWOK, EDWARD NG Creating breathing cities by adopting urban ventilation assessment and wind corridor plan The implementation in Chinese cities. Journal of Wind Engineering and Industrial Aerodynamics, 182, 170, 2018.

25. GUO FEI, ZHANG HONGCHI, FAN YUE, ZHU PEISHEN, WANG SHIYUAN, LU XIAODONG, JIN YUN Detection and evaluation of a ventilation path in a mountainous city for a sea breeze: The case of Dalian. Building and Environment, 145, 177, 2018.

26. EDWARD NG, CHAO YUAN, LIANG CHEN, CHAO REN, JIMMY C.H. FUNG Improving the wind environment in high-density cities by understanding urban morphology and surface roughness: A study in Hong Kong. Landscape and Urban Planning, 101, 59, 2011.

27. LAN CHEN, JIAN HANG, MATS SANDBERG, LEIF CLAESSON, SILVANA DI SABATINO, HANS WIGO The impacts of building height variations and building packing densities on flow adjustment and city breathability in idealized urban models. Building and Environment, 118, 344, 2017.

28. RICCARDO BUCCOLIERI, JIAN HANG Recent Advances in Urban Ventilation Assessment and Flow Modelling. Atmosphere, 10, 144, 2019.

29. CHIEN-YUAN KUO, RONG-JING WANG, YI-PIN LIN, CHI-MING LAI Urban Design with the Wind: PedestrianLevel Wind Field in the Street Canyons Downstream of Parallel High-Rise Buildings. Energies, 13, 2827, 2020.

30. JIAN HANG, LAN CHEN, YUANYUAN LIN, RICCARDO BUCCOLIERI, BORONG LIN The impact of semi-open settings on ventilation in idealized building arrays. Urban Climate, 25, 196, 2018.

31. YU-HSUAN JUAN, AN-SHIK YANG, CHIH-YUNG WEN, YEE-TING LEE, PO-CHUN WANG Optimization procedures for enhancement of city breathability using arcade design in a realistic high-rise urban area. Building and Environment, 121, 247, 2017. 
32. HUANG TZU-LING, KUO CHIEN-YUAN, TZENG CHUN-TA, LAI CHI-MING The Influence of High-Rise Buildings on Pedestrian-Level Wind in Surrounding Street Canyons in an Urban Renewal Project. Energies, 13 (11), 2020.

33. LI MENGXI, QIU XINFA, SHEN JUANJUN, XU JINQIN, FENG BO, HE YONGJIAN, SHI GUOPING, ZHU XIAOCHEN CFD Simulation of the Wind Field in Jinjiang City Using a Building Data Generalization Method. Atmosphere, 10 (6), 2019.
34. BADAS MARIA GRAZIA, FERRARI SIMONE, GARAU MICHELA, SEONI ALESSANDRO, QUERZOLI GIORGIO On the Flow Past an Array of TwoDimensional Street Canyons Between Slender Buildings. Boundary-Layer Meteorology, 174 (2), 251, 2019.

35. PENG YUNLONG, GAO ZHI, BUCCOLIERI RICCARDO, DING WOWO An Investigation of the Quantitative Correlation between Urban Morphology Parameters and Outdoor Ventilation Efficiency Indices. Atmosphere, 10 (1), 2019. 